\title{
Development of an Index for Assessing Farm Women's Access to Resources
}

\author{
Ananta Sarkar, Shivaji Argade ${ }^{*}$ and J. Charles Jeeva \\ ICAR-Central Institute for Women in Agriculture, Bhubaneswar, Odisha-751003, India \\ *Corresponding author
}

\begin{tabular}{|c|c|}
\hline & A B S T R A C T \\
\hline $\begin{array}{l}\text { K e y w o r d s } \\
\text { Farm women, Index, } \\
\text { Access to resource, } \\
\text { Guilford method, } \\
\text { Normalised rank order } \\
\text { method }\end{array}$ & \multirow{3}{*}{$\begin{array}{l}\text { The status of farm women's access to resources is considered to be critical as a determinant } \\
\text { and necessary precondition for their progress. Access to Resource Index is designed for } \\
\text { assessing the status of farm women's access to resources. It constitutes five dimensions and } \\
40 \text { indicators. The specific weightage of each dimension in an index is calculated using } \\
\text { Normalised Rank Order Method. Indicators had at least } 80 \% \text { expert's agreement are } \\
\text { retained in the final index. Index content is standardised by evaluating the content validity } \\
\text { and expert opinions. It assesses the status of access to resources in terms of availability, } \\
\text { affordability, suitability and capability to use resources. It emphasises the dimensions of } \\
\text { resources which required immediate attention and needs to target in the policy initiatives } \\
\text { for sustaining the livelihood of farm women. It can be used to measure and compare the } \\
\text { status of farm women's access to resources in different regions of India with suitable } \\
\text { modifications and validation. }\end{array}$} \\
\hline Article Info & \\
\hline $\begin{array}{l}\text { Accepted: } \\
\text { 07 January } 2018 \\
\text { Available Online: } \\
\text { 10 February } 2018\end{array}$ & \\
\hline
\end{tabular}

\section{Introduction}

Since birth of farming, women are backbone of the agricultural workforce. Today, they represent $43 \%$ of the global agricultural labour force. The percentage of women who depend on agriculture for their livelihood is as high as $84 \%$ in India. About $79 \%$ of women continue to be engaged in agriculture and allied activities as against only $63 \%$ of men. Women cultivators and agriculture labourers perform $70 \%$ of all the agriculture activities. About $12 \%$ of all rural households in India are now female headed with small holdings. The increasing number of farmer suicides, $40 \%$ male farmers want to quit farming and rural youth migration towards non-farm employment are forcing women's to shoulder household as well as farm responsibilities (NSSO, 2010). Even though women are major contributors to food production, they lag well behind men in access to productive resources and income from them. If women had provided the same access to productive resources as men, they could boost yield by 20-30\% (FAO, 2011).

Farm women are mostly dependent on the natural resources for their livelihood. Hence, their livelihood is directly impacted by scarcity of natural resources. Inadequate access to productive resources limits women's livelihood options and exacerbates financial strain on women. By improving farm women's access to productive resources, their potential could be unlocked, thereby enhancing their 
efficiency and productivity. Therefore, the status of farm women's access to resources in different regions is need to assessed for designing suitable strategies to improve their access to resources. But, there is no such standardized tool/index available for assessing the same. Indices of socio-economic security are composite indicators of the socioeconomic wellbeing at the individual, community, state, national and international levels (Estes, 1997; Klein, 2003 and Sharpe, 1999).

These socio-economic indicators are used to help in the identification of problem-areas that need policy planning and require intervention to alter the course of action. On the basis of these well-known composite indexes of socioeconomic wellbeing are Livelihood Index by Anil et al., (2008), Human Development Index by UNDP (1989), Gender-related Development Index, Gender Empowerment Measure, Quality of Life Index by Diener (1995) and Access to Seed Index by Verhagen (2015), an attempt was made to develop Access to Resource Index (ARI) for assessing the status of farm women's access to resources coupled with meeting the basic resource needs of farm women.

It will be the standardised tool to measure and compare the status of farm women's access to resources in different regions of India. It emphasises the dimensions of resources which required immediate attention and needs to target in the policy initiatives for sustaining the livelihood of farm women.

\section{Conceptual framework}

Access is defined as the opportunity to make optimum use of available resources. A resource is a source or supply of goods and services which is used to get better output. Access to resources is consists of following four components;

\section{Availability}

Are resources available as per the needs of farm women? This refers to whether sufficient resources are available within proximity, in time and in reliable supply.

\section{Affordability}

Can farm women afford to use quality resources? This refers to whether farm women having the means to purchase or avail the resources.

\section{Suitability}

Are the resources tailored to the needs of farm women? This refers to whether available resources are suitable for the needs and local condition of farm women.

\section{Capability}

Arefarm women having the ability and skill to make use of resources? This refers to whether farm women have capacity and favourable social climate to make effective use of available resources.

\section{Development of Access to Resource Index (ARI)}

\section{Selection of dimensions}

The resource has multidimensional aspects. Therefore, it is imperative to select representative dimensions of resources. These dimensions are selected from available literature and threadbare discussion with experts in field of agriculture. Broadly, these dimensions are operationalised as;

\section{Human resource}

It represents the skills, knowledge, nutrition and good health that together enable people to 
produce goods or render services like training, extension, information, banking, etc. Human resources are the people needed to provide services to farm women.

\section{Physical resource}

It is basic infrastructural asset and producer good needed to meet basic needs and to be more productive. These are water supply, sanitation, gender friendly farm technologies, means of transportation, market, farm inputs, shelter, electricity, ICTs, etc.

\section{Natural resource}

It is resource or asset from nature useful for livelihood. These are land, livestock, air, water, forest, etc.

\section{Social resource}

It is defined as the social asset which forms social safety networks for creating women friendly environment. These are management skills, decision making, communication skills, social protection services, trust and solidarity among members of the society, effective means to utilise leisure time, equal social status, etc.

\section{Financial resource}

It is financial asset flows as well as stocks and contributes to consumption as well as production. It enables people to adopt different livelihood strategies. These are farm income, savings, farm subsidies, credit, microfinance, insurance, employment, property/land rights, etc.

\section{Selection of indicators}

The selection of relevant indicators for measuring any dimension is an important step of index methodology. Hence, all the relevant indicators under each dimension were collected from available literature and consultation with researchers, extension workers and innovative farm women. Total 70 indicators were collected edited as per 14 informal criteria suggested by Edwards (1957) as result 10 indicators were eliminated. Finally, 60 indicators were retained after editing and considered for expert's evaluation.

\section{Expert's response to dimensions and respective indicators}

The perform a containing five dimensions and their respective indicators was sent through email as well as handed over personally to more than 50 experts who were renowned persons in the field of social science, agricultural extension, gender studies and rural development. Experts were asked to rank five dimensions (1 to 5) according to their importance to farm women. Expert's were also asked to give response to each indicator on three point continuums i.e. Most relevant, Relevant and Least relevant. They were requested to make necessary modifications, additions and deletions in listed indicators, if they desired so. About 35experts had given their response in a stipulated span of one month. After careful examination of responses, 5 responses were found unsuitable for further item analysis and eliminated. The remaining 30 responses were considered for the determination of scale values of dimensions and relevancy of indicators.

\section{Determination of scale values for each dimension}

The Normalized Rank Order Method suggested by Guilford (1954) was used for determining the scale values to each dimension based on their perceived significance to farm women's development. The method has got a unique advantage that it can be used with any number of variables and 
does not require a large number of experts. The rankings given by all 30 experts were summarised and presented in Table 1. Further, the proportion (p) were worked out for the ranks. The $p$ value is centile value which indicated the area of the dimensions in the normal distribution. Thus, the $\mathrm{p}$ values for the ranks ranged from the lowest 10 to the highest 90 (Table 1). The $\mathrm{C}$ values were obtained for each rank from the Table-M (Guilford, 1954) and represented in Table 1 under the column C.

The next step was to find out the $\sum \mathrm{f}_{\mathrm{ji}} \mathrm{C}$ value for all the dimensions. This was obtained by multiplying the rank frequencies of respective dimension by the $\mathrm{C}$ values of respective rank $\left(\mathrm{r}_{\mathrm{i}}\right)$ and summing up the products for each dimension. Then, $\sum \mathrm{f}_{\mathrm{ji}} \mathrm{C}$ values of each dimension was divided by total number of experts (30), which resulted in obtaining the scale values $\left(R_{c}\right)$ for each dimension.

The obtained scale values for human resource, physical resource, natural resource, social resource and financial resource are 6.6, 6.1, $6.9,5.9$ and 6.5 respectively. The cross check for this method is that the sum of obtained scale values and sum of $\mathrm{C}$ values should be same. The sum of obtained scale values and sum of $\mathrm{C}$ values was same i.e. 32. This proves the reliability of procedure followed for calculation of scale values. The mean and standard deviation of scale values are 6.4 and 0.4 , respectively. The standard error for scale values is only 0.07 which shows the accuracy of the method followed for obtaining scale values.

\section{Relevancy test for each indicator}

Item analysis is an important step while constructing valid and reliable index. It is possible that all the indicators collected may not be relevant equally in measuring access to resources. Hence, these indicators were subjected to scrutiny and their subsequent screening for inclusion in the final index. Experts were asked to indicate degree of relevancy on each indicator with three point continuums i.e. Most relevant, Relevant and Least relevant with scoring 3, 2, and 1, respectively. The Relevancy Weightage (RW) and Mean Relevancy Score (MRS) were worked out for all the selected indicators individually (Table 2) by using the following formulas;

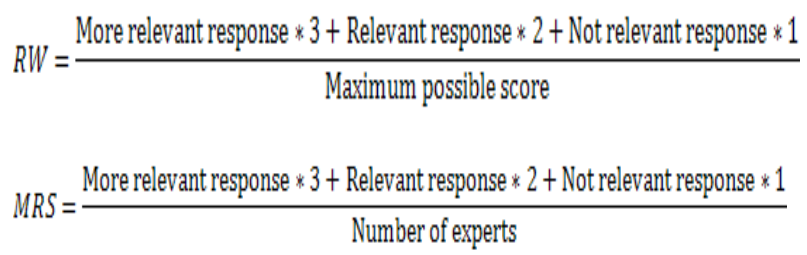

The obtained average values of RW and MRS were 0.80 and 2.50 , respectively. By using these two values, the indicators having RW $>0.80$ and MRS >2.50were considered for including in the final index. As a result out of 60 indicators, 40 indicators were selected to include in final index (Table 2). The selected indicators are modified and rewritten as per the comments of experts.

\section{How the index works}

The various set of items/statements should be prepared under each indicator for final data collection from the respondents. The prepared set of items/statements should consider the availability of resources, affordability of farm women, suitability of resources and capability of farm women to use resources.

Further, the response of farm women on prepared items/statements should be reported on three point or five point continuums. Then, the relevant scores should be assigned to each response for quantification of collected data. Finally, the sum of score obtained under each dimension of the index can be used for the computation of the composite index. 
Table. 1 The frequencies of ranks as given by 30 experts, proportions (p), $C$ values and $R_{c}$ values for five dimensions of access to resource index

\begin{tabular}{|c|c|c|c|c|c|c|c|c|c|}
\hline \multirow[t]{2}{*}{$\mathbf{r}_{\mathbf{i}}$} & \multirow[t]{2}{*}{$\mathbf{R}_{\mathbf{i}}$} & \multicolumn{5}{|c|}{ Five dimensions of resources } & \multirow{2}{*}{$\begin{array}{c}\text { Sum } \\
(\Sigma)\end{array}$} & \multirow{2}{*}{$\begin{array}{l}\text { Proportion(p) } \\
=\frac{R_{j}-10.51100}{n}\end{array}$} & \multirow{2}{*}{$\begin{array}{l}\text { C values of respective } \\
\text { ranks }(\mathrm{C})\end{array}$} \\
\hline & & $\begin{array}{c}\text { Human } \\
\text { Resource }\end{array}$ & $\begin{array}{l}\text { Physical } \\
\text { Resource }\end{array}$ & $\begin{array}{l}\text { Natural } \\
\text { Resource }\end{array}$ & $\begin{array}{c}\text { Social } \\
\text { Resource }\end{array}$ & $\begin{array}{l}\text { Financial } \\
\text { Resource }\end{array}$ & & & \\
\hline 1 & 5 & 7 & 4 & 12 & 3 & 4 & 30 & 90 & 8 \\
\hline 2 & 4 & 8 & 3 & 6 & 5 & 11 & 30 & 70 & 7 \\
\hline 3 & 3 & 8 & 9 & 4 & 5 & 4 & 30 & 50 & 6 \\
\hline 4 & 2 & 3 & 7 & 6 & 5 & 7 & 30 & 30 & 6 \\
\hline 5 & 1 & 4 & 7 & 2 & 12 & 4 & 30 & 10 & 5 \\
\hline \multicolumn{2}{|c|}{$\sum \mathbf{f}_{\mathrm{ji}}$} & 30 & 30 & 30 & 30 & 30 & 150 & & \multirow{2}{*}{$\begin{array}{c}32 \\
\text { (Sum of } \mathrm{C} \text { values) }\end{array}$} \\
\hline \multicolumn{2}{|c|}{$\sum \mathbf{f}_{\mathrm{ji}} \mathbf{C}$} & 198 & 184 & 208 & 179 & 195 & 964 & & \\
\hline \multicolumn{2}{|c|}{$\begin{array}{c}\mathbf{R}_{\mathbf{c}} \\
\left(\sum \mathbf{f}_{\mathbf{j i}} \mathbf{C} / \mathbf{N}\right)\end{array}$} & 6.6 & 6.1 & 6.9 & 5.9 & 6.5 & 32 & \multicolumn{2}{|c|}{$\begin{array}{c}\text { Mean of } R_{c}\left(M_{c}\right)=6.4 \\
\text { Standard Deviation of } R_{c}(\sigma)=0.4\end{array}$} \\
\hline \multicolumn{7}{|c|}{$\begin{array}{c}\mathbf{r}_{\mathrm{i}}=\text { Correct rank order, } \mathbf{R}_{\mathrm{i}}=\text { Reverse rank order, } \mathbf{n}=\text { Number of dimensions } \\
(\mathbf{5}), \mathbf{f}_{\mathrm{j}}=\text { Rank frequency, } \mathbf{R}_{\mathrm{c}}=\text { Scale value and } \mathbf{N}=\text { Number of experts }(\mathbf{3 0})\end{array}$} & \multicolumn{3}{|c|}{ Standarderrorfor $R_{c}=\frac{\sigma}{\sqrt{\mathrm{N}}}=\frac{0.4}{\sqrt{30}}=\frac{0.89}{5.48}=0.07$} \\
\hline
\end{tabular}


Table.2 Dimensions and respective indicators of ARI with their relevancy weightage and mean relevancy score

\begin{tabular}{|c|c|c|}
\hline Resource dimensions and respective indicators & $\begin{array}{l}\text { Relevancy } \\
\text { weightage }\end{array}$ & $\begin{array}{l}\text { Mean } \\
\text { relevancy score }\end{array}$ \\
\hline Human Resource & & \\
\hline Access to sufficient food & 0.97 & 2.90 \\
\hline Access to health services & 0.96 & 2.87 \\
\hline $\begin{array}{l}\text { 3) Access to natural calamity protection } \\
\text { services }\end{array}$ & 0.91 & 2.73 \\
\hline Access to nutritional diet & 0.90 & 2.70 \\
\hline Access to banking services & 0.90 & 2.70 \\
\hline Access to social protection services & 0.84 & 2.53 \\
\hline Access to training services & 0.82 & 2.52 \\
\hline Access to veterinary services & 0.81 & 2.51 \\
\hline 9) Access to extension services & 0.81 & 2.51 \\
\hline *Access to family labour & 0.76 & 2.27 \\
\hline 11) *Access to government officials & 0.74 & 2.23 \\
\hline 12) *Access to hired labour & 0.69 & 2.07 \\
\hline Physical Resource & & \\
\hline 13) Access to water supply and sanitation & 0.94 & 2.83 \\
\hline 14) Access to women friendly farm technologies & 0.92 & 2.77 \\
\hline 15) Access to means of transportation & 0.89 & 2.67 \\
\hline 16) Access to market & 0.89 & 2.67 \\
\hline 17) Access to critical crop \& livestock inputs & 0.88 & 2.63 \\
\hline 18) Access to agricultural information & 0.88 & 2.63 \\
\hline 19) Access to pucca house & 0.86 & 2.57 \\
\hline 20) Access to basic household amenities & 0.84 & 2.53 \\
\hline 21) Access to electricity & 0.82 & 2.52 \\
\hline 22) Access to modern ICTs & 0.82 & 2.52 \\
\hline 23) *Access to animal housing & 0.79 & 2.37 \\
\hline 24) *Access to traditional ICTs & 0.77 & 2.30 \\
\hline 25) *Access to mechanised farm equipments & 0.73 & 2.20 \\
\hline 26) *Access to non-mechanised farm equipments & 0.70 & 2.10 \\
\hline Natural Resource & & \\
\hline Access to agricultural land & 0.94 & 2.83 \\
\hline Access to small livestock rearing & 0.91 & 2.73 \\
\hline Access to healthy environment & 0.83 & 2.52 \\
\hline Access to irrigation & 0.81 & 2.51 \\
\hline Access to fuel sources & 0.81 & 2.51 \\
\hline *Access to grazing land & 0.77 & 2.30 \\
\hline *Access to large livestock rearing & 0.74 & 2.23 \\
\hline *Access to waste assimilation facilities & 0.74 & 2.23 \\
\hline *Access to non-agricultural land & 0.73 & 2.20 \\
\hline
\end{tabular}




\begin{tabular}{|c|c|c|c|}
\hline 36) & *Access to erosion protection methods & 0.69 & 2.07 \\
\hline 37) & *Access to non timber forest products & 0.66 & 1.97 \\
\hline D) & \multicolumn{3}{|l|}{ Social Resource } \\
\hline 38) & Access to develop management skills & 0.87 & 2.60 \\
\hline 39) & Access to trust and solidarity & 0.87 & 2.60 \\
\hline 40) & Access to decision making & 0.87 & 2.60 \\
\hline 41) & Access to equal intra-house communication & 0.84 & 2.53 \\
\hline 42) & Access to equal intra-house status & 0.82 & 2.52 \\
\hline 43) & Access to utilise leisure time & 0.81 & 2.51 \\
\hline 44) & *Access to leadership development & 0.77 & 2.30 \\
\hline 45) & *Access to socio-political participation & 0.71 & 2.13 \\
\hline E) & \multicolumn{3}{|l|}{ Financial Resource } \\
\hline 46) & Access to farm income & 0.93 & 2.80 \\
\hline 47) & Access to savings & 0.90 & 2.70 \\
\hline 48) & Access to farm subsidies & 0.90 & 2.70 \\
\hline 49) & Access to credit facilities & 0.89 & 2.67 \\
\hline 50) & Access to microfinance & 0.88 & 2.63 \\
\hline 51) & Access to Self Help Groups & 0.88 & 2.63 \\
\hline$\overline{52)}$ & Access to insurance & 0.87 & 2.60 \\
\hline 53) & Access to farm employment & 0.86 & 2.57 \\
\hline $\begin{array}{l}\text { 54) } \\
\text { pro }\end{array}$ & $\begin{array}{l}\text { Access to remunerative prices for farm } \\
\text { ce }\end{array}$ & 0.86 & 2.57 \\
\hline 55) & Access to property rights & 0.84 & 2.53 \\
\hline 56) & *Access to remittance transfers & 0.78 & 2.33 \\
\hline 57) & *Access to non- farm income & 0.77 & 2.30 \\
\hline 58) & *Access to non-farm employment & 0.77 & 2.30 \\
\hline 59) & *Access to cash in hand & 0.60 & 1.77 \\
\hline \multirow[t]{2}{*}{ 60) } & *Access to jewellery & 0.58 & 1.73 \\
\hline & Mean & 0.80 & 2.50 \\
\hline
\end{tabular}

\section{Computation of the composite index}

Each dimension consists of different number of indicators. Hence, the range of total score is different for each dimension. Therefore, the obtained total score of each dimension is necessary to convert into unit score for bringing uniformity in the score of all dimensions. This is calculated by using the following formula;

$U_{i j}=\frac{Y_{i j}-\operatorname{Min} Y_{i j}}{\operatorname{Max} Y_{j}-\operatorname{Min} Y_{j}}$
Where,

$\mathrm{U}_{\mathrm{ij}}=$ Unit score of the $\mathrm{i}^{\text {th }}$ respondents on $\mathrm{j}^{\text {th }}$ dimension

$Y_{i j}=$ Value of the $i^{\text {th }}$ respondent on the $j^{\text {th }}$ dimension

Max $Y_{j}=$ Maximum score on the $j^{\text {th }}$ dimension

Min $\mathrm{Y}_{\mathrm{j}}=$ Minimum score on the $\mathrm{j}^{\text {th }}$ dimension

Thus, the unit score of each dimension ranges 
from 0 to 1 . Further, the composite index value for each respondent is calculated by the following formula;

$A R I_{i}=\frac{\sum U_{i j} * S_{j}}{\text { Sumofscalevalues }}$

Where,

$\mathrm{ARI}_{\mathrm{i}}=$ Access to Resource Index of $\mathrm{i}^{\text {th }}$ respondent

$U_{i j}=$ Unit score of the $i^{\text {th }}$ respondent on $j^{\text {th }}$ dimension

$S_{j}=$ Scale value of the $j^{\text {th }}$ dimension

$\sum=\operatorname{Sum}$

The composite index value ranges from 0 to 1. When it is minimum, the value is 0 and when it is maximum the value is 1 . Based on composite index value of respondents, the respondents can be categorised into different categories of low, medium and high level of access to resources by cumulative square root of frequency method.

\section{Standardisation of an index}

The validity was ascertained for standardisation of the index. It is the property that ensures the obtained test scores as valid, if and only if it measure what it is supposed to measure. The validity of an index is measured by content validity. The content validity is the representative or sampling adequacy of the content of a measuring instrument.

The content of an index was covered through available literature scan and expert opinions. The indicators had at least 80\%expert's agreement are retained in the final index. As the scale values of dimensions and, relevancy weightage and mean relevancy score of indicators had discriminating values, it seemed reasonable to accept the index as valid measure of the desired variable.

ARI as a composite index of its five dimensions of human resource, physical resource, natural resource, social resource and financial resource works as a standardised tool for assessing the status of farm women's access to resources which is priceless resource to policy makers for designing innovative strategies. A developed index can measure the extent to which the farm women's have access to resources and which kind of resources can be provided to benefit farm women. It analyses access to resources in terms of availability, affordability, suitability and capability. The content validity of an index indicates the precision and consistency of the results. This index can be used to assess the status of farm women's access to resources in different regions of India with suitable modifications and evaluation of validity of an index.

\section{References}

Anil R., Sharma, S. D., Prachi, M. S. and Malhotra, P. K. 2008. Development of livelihood index for different agroclimatic zones of India. Agricultural Economics Research Review, 21, 173182.

Diener, E. D. 1995. A value-based index for measuring national quality of life. Social Indicators Research, 36, 107127.

Edwards, A. L. 1957. Techniques of attitude scale construction. Vakils, Feffer and Simons Private Ltd., Bombay.

Estes, R. J. 1997. Social development trends in Europe: 1970-1994 Development prospects for New Europe. Social Indicators Research, 42, 1-19.

FAO. 2011. The State of Food and Agriculture 2010-11. Women in Agriculture: Closing the gender gap for 
development, Rome.

Guilford, J. P. 1954. Psychological methods. Tata McGraw Hill Publishing Co. Ltd.

Klein, L. R. and Ozmucur, S. 2003. The estimation of China's economic growth. Journal of Economic and Social Measurements, 62(8), 187-202.

Sharpe, A. 1999. A Survey of Indicators of economic and social well-being,
Canada: Center for study of living standard.

United Nations Development Program. 1989. Human development report. New York: Oxford university press.

Verhagen, I. and Cecily, L. 2015. Methodology report for the access to seed index. Access to Seeds Foundation, Netherland.

\section{How to cite this article:}

Ananta Sarkar, Shivaji Argade and Charles Jeeva, J. 2018. Development of an Index for Assessing Farm Women's Access to Resources. Int.J.Curr.Microbiol.App.Sci. 7(02): 610-618. doi: https://doi.org/10.20546/ijcmas.2018.702.076 